the usual annual one, as it is now issued in August instead of January to coincide with the financial year of the Wattle Growers Union. The change, says the report, has enabled work in progress to be reported up to a well-defined seasonal phase and has allowed the writing-up to be done at a time of the year when the demands of field work are less insistent-points which will be understood by all field practical research workers. Considerable work has been carried out on the buildings of the Institute and the lay-out of the farm, with a planned road system which will comprise some twenty-two miles when completed. Some eighty acres of the farm have now been planted for experiments. Improvements have been made to the nursery, and a small plantation of black wattle has been established to facilitate ad hoc tests of the effect of insecticides, weed-control chemicals, and so forth. Part 1 of the report deals with administration, and Part 2 with research, including sylviculture, genetics and plant breeding, chemistry and entomology. Progress reports include one by $\mathrm{H}$. Shaw, the director of the Institute, entitled "Natal, Home of the Union Wattle Industry". Filling of research-staff posts has proved somewhat difficult, especially the junior posts, in which there is a high wastage of junior assistants owing to resignations after a short period of service. Improved conditions of service are now being introduced.

Carnegie Trust for the Universities of Scotland : Annual Report for 1951-52

The fifty-first annual report of the Carnegie Trust for the Universities of Scotland (pp. 80; Carnegie Trust, Edinburgh, 1953) covers the academic year 1951-52 and includes the following items: the abstract of accounts; a summary of grants for the period October 1, 1952-September 30,1957 ; a report upon the work of investigators under the research scheme during the year ; a list of publications by fellows, scholars and recipients of grants since September 30, 1951; a list of awards for the year 1952-53; and details of assistance to students. Of the $£ 37,365$ distributed on research schemes during the year, $£ 19,395$ went to fellowships and scholarships ; $f 4,000$ in block grants to the four universities, for use at their discretion in assisting professors, readers, lecturers and assistants on research projects during vacations; $£ 2,645$ to the new scheme by which not more than ten specially selected members of the university staffs were given opportunity for travel and maintenance abroad on research; and $£ 8,160$ for grants in aid of research. $£ 3,165$ was set aside to give partial guarantee against loss on publication of works of high merit. Reverting to the pre-war practice of utilizing for current income the annual interest from the general reserve fund and the fund founded from repayments by former beneficiaries (which increased during 1951-52 to £1,985 from thirty-six former beneficiaries), the executive aommittee from an annual income of approaching $£ 127,000$ offered to the Universities of St. Andrews and Aberdeen $£ 50,000$ in all, spread over the next quinquennium, 1952-57, subject to approval of the proposed use by the committee. $£ 80,000$ each was similarly offered to the Universities of Glasgow and Edinburgh, with $£ 23,000$ during the period to the extra-mural colleges. In regard to applications for fellowships and scholarships, the executive committee points out that a number of applications received should more properly have gone to the Department of Scientific and Industrial Research.
The scheme for the endowment of postgraduate study and research is appended to the report, and the committee directs attention to the second paragraph of the scheme which indicates that where science scholarships are concerned, more especially in physics and chemistry, the committee reserves the right to give preferential treatment to applicants ineligible to receive allowances from the Department of Scientific and Industrial Research.

\section{Journal of Histochemistry and Cytochemistry}

Two numbers of the new Journal of Histochemistry and Cytochemistry have now appeared. The new journal is edited by R. D. Lillie for the American Histochemical Society and is published by Williams and Wilkins ( $£ 3$ a year, post-paid). There will at present be six numbers a year, giving an aggregate of about 500 pages per volume. Manuscripts, books for review and all inquiries concerning material should be addressed to Dr. R. D. Lillie, National Institutes of Health, Bethesda 14, Maryland, U.S.A. At present, papers on histochemistry and cytochemistry are widely scattered through the literature. No doubt this will continue to be the case; but workers in these fields will welcome a journal which is primarily devoted to cytochemistry, particularly if the new journal concentrates on methods. Papers which are primarily studies of biological problems, and which incidentally make use of histochemical and cytochemical methods, will more properly find their places in older journals. But there is a great field of investigation of cytochemical methods, much of which is highly controversial : studies in this field will find a more appropriate home in the new journal. Each number of the new journal will also include a list of current papers on histochemistry published in other journals.

\section{Royal Scottish Museum, Edinburgh : Report for} 1952

The annual report of the Royal Scottish Museum for 1952, while recording the normal activities of display and the systematic arrangement of reserve material, emphasizes the important part played by the staff in various educational and cultural organizations. To mention only a few examples, the director, Dr. D. A. Allan, is one of the two British members of the executive of the International Council of Museums and acts as assessor and consultant in connexion with the award of Carnegie grants to Scottish Museums; Mr. Cyril Aldred is honorary secretary of the Scottish Federation of Museums and Art Galleries; and Dr. A. C. Stephen acts as examiner for the diploma of the Museums Association. The sum total of the activities of the staff in local, national and international organizations forms an impressive record.

\section{United States National Museum}

THE annual reports of the United States National Museum for 1951 and 1952 well illustrate the balance it is always necessary to keep in a well-planned museum between direct and indirect service to the public. Direct service is through exhibits, talks to visiting groups, answering of inquiries; while the indirect service to the community is through the cataloguing, indexing and research on the collections. From the point of view of the staff of a museum, it may be said that the effective performance of both these functions depends on that essential element in the work of a successful museum, namely, research. 